\title{
Camões e a Química. A Química em Camões
}

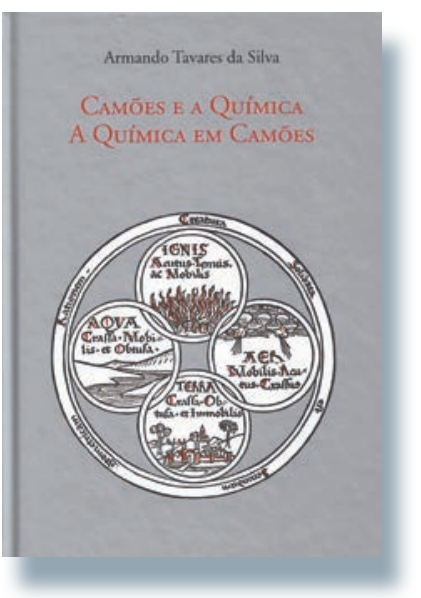

Armando Tavares da Silva doutorou-se em Engenharia Química pela Universidade de Cambridge (Reino Unido), em 1967. Foi docente do Instituto Superior Técnico e Professor Catedrático na Faculdade de Ciências e Tecnologia da Universidade de Coimbra. Aposentado em 2002, dedica-se à investigação histórica.

Como é salientado pelo autor, são escassos os documentos seguros que permitam reconstruir a biografia de Camões. A incerteza inclui até o ano e lugar do seu nascimento. No livro em causa aprende-se que a data de nascimento oficialmente aceite (1524) é refutada por alguns historiadores, que apontam o ano de 1531 como sendo o mais provável. Ora se muito pouco se conhece da vida de Camões, menos se sabe sobre o seu interesse pela Química-ou, melhor dizendo, pela alquimia, uma vez que só no século XVIII se começou a racionalizar o conhecimento químico. É também impossível saber
Autor: Armando Tavares da Silva

Edição do autor

ISBN: 978-989-202-085-3

se Camões conheceu algumas obras cujo conteúdo se situava no âmbito da futura ciência química, como o De re metallica, de Georgius Agricola.

Por outro lado, analisando a obra do poeta, já é possível aprender qual a Química em Camões. Foi essa análise que o Prof. Tavares da Silva fez. N'Os Lusíadas, vemos que Camões menciona ferro, cobre, estanho, ouro e prata. Mas, no século XVI, ainda em pleno Renascimento, a "química" era dominada pelos elementos dos gregos - fogo, ar, água e terra. Camões menciona-os não apenas n'Os Lusíadas mas também na sua obra lírica. Para aguçar o apetite do leitor transcrevo abaixo um dos seus sonetos.

Foi um prazer (embora breve!) ler o livro do Prof. Tavares da Silva, e ver/rever uma seleção iconográfica, também apresentada no livro, sobre a Química na literatura científica e na arte entre 1530 e 1671.

\author{
José Artur Martinho Simões*
}

Ar, que de meus suspiros vejo cheio, Terra, cansada já com meu tormento, Água, que com mil lágrimas sustento, Fogo, que mais acendo no meu seio:

Em paz estais em mim, e assim o creio,

Sem esse ser o vosso próprio intento, Pois em dor onde falta sofrimento,

A vida se sustém por vosso meio.

$A i$, imiga Fortuna! Ai, vingativo Amor! A que discursos por vós tenho, Sem nunca vos mover com minha mágua!

Se me quereis matar, para que vivo? E como vivo, se contrários tenho Amor, Fortuna, Ar, Terra, Fogo e Água?

\footnotetext{
* Faculdade de Ciências da Universidade de Lisboa E-mail: jamsimoes@fc.ul.pt
}

\section{Vá a www.spq.pt}

Torne-se Sócio da Sociedade Portuguesa de Química e beneficie de:

- Pertencer a uma comunidade científica dinâmica;

- Receber o boletim "QUÍMICA";

- Descontos nos Encontros promovidos pela SPQ;

- Descontos nas publicações da SPQ;

- Protocolos assinados entre a SPQ e outras entidades;

- Participar na promoção da Química;

- Apoiar uma Sociedade Científica. 